Saikia, P., Raj, M., Deka, J. and Bhattacharjee, P.C. 1990. New golden langur records. Oryx, 24, 194. Varley, H. 1985. A rare sighting of the golden langur. Oryx, 19, 196.

Anwaruddin Choudhury, Near Gate No. 1 of Nehru Stadium, Islampur Road, Guwahati 781 007, Assam, India.

\section{Chek Lap Kok - how important is it?}

I write regarding David Dudgeon's letter about Chek Lap Kok (Oryx, 26, 53), site for Hong Kong's proposed new airport. I led teams of professional biologists and field assistants in a 7-month comparative study of Chek Lap Kok and nearby islands during 1990-1991. The island was about $3 \mathrm{sq} \mathrm{km}$ and about 20 per cent marshland. The two mangrove swamps, albeit small, were excellent indeed, containing a Bruguiera now reduced to extreme rarity this far north.

All mangroves in China are tiny patches. The only two that compare in size are at Mai Po, Hong Kong, and Deng Zhai Kong, Hainan Dao. It is said that no mangrove at all remains in Guangdong or Guanxi Provinces except that at Deep Bay, adjacent to Mai Po.

Not one square centimetre of all South China is free from human impact. Chek Lap Kok, however, supported an amazing diversity of animals - at least three times more nonflying vertebrate species than are known from any other South China Sea island of comparable size. Dudgeon implies that our tally of 32 amphibians, reptiles and non-flying mammals was wrong. Voucher specimens for all 30 reptiles and amphibians are in the Museum of Comparative Zoology at Harvard and both native mammals are in Peabody Museum, Yale. Chek Lap Kok was an amazing place. James Lazell, The Conservation Agency, 6 Swinburne Street, Jamestown, Rhode Island 02835, USA.

\section{David Dudgeon responds:}

Firstly, I did not intend to dispute the count of 32 amphibians, reptiles and non-flying mammals. The original article in Oryx $(25,192) \mathrm{did}$ not refer to reptiles and amphibians but to ter- restrial vertebrates. Most of the vertebrates on the islands are birds and these are largely species that are widely distributed in the Territory. Secondly, the Chek Lap Kok mangrove stands are small, and are not the only (nor the largest) stands in the area (Lantau etc.) that contain Bruguiera. They could not be described accurately as 'excellent mangrove swamps'. Your assertion that Chek Lap Kok supports at least three times more non-flying vertebrate species than are known from any other South China Sea island of comparable size does not surprise me because of, (a) the proximity to Lantau (cf. island biogeography theory), and (b) the relatively large collecting effort undertaken on Chek Lap Kok compared with other islands in the South China Sea. Once equivalent effort has been put into the other islands we will be in a better position to assess their relative conservation value.

Unlike Lazell, I do not regard Chek Lap Kok as being especially important in the Hong Kong or South China context. There are other sites within the territory that are under threat of development, which are much more diverse biologically. With the exception of its role as habitat for Philautus romeri, I believe that Chek Lap Kok has less conservation value than Sha Lo Tung, Luk Keng and other sites scheduled for development.

David Dudgeon, Department of Zoology, The University of Hong Kong, Hong Kong.

\section{To collect or not to collect - a conservation issue?}

From their letters (Oryx, 26, 52-53 and 119-121), it would appear that Dr R. Hutterer, Mr W. F. Ansell and Dr W. R. P. Bourne have either not read my earlier letter (Oryx, 26, 52) properly, or else have totally failed to comprehend the point I was trying to make.

While, of course, I accept Mr Ansell's truisms that the way to conserve wild animals is to ensure that there is a viable population in a viable habitat' and that 'wildlife conservation requires knowledge of the species occurring and their biology', I strongly dispute his contention that 'collection of study specimens is 
essential for conservation to have the proper scientific basis' and that of Dr Bourne that 'it is still sometimes important for purposes of both conservation and the advancement of knowledge that examples of potential new forms should be placed on record as soon as possible', as well as Dr Hutterer's claim that 'to obtain the primary information, collection of specimens is often required'.

The point I was, apparently unsuccessfully, endeavouring to make, was that the advent of deoxyribonucleic acid (DNA) genetic 'fingerprinting', coupled with modern photographic, videotaping and sound-recording techniques, makes it perfectly possible to demonstrate the existence of new forms without the necessity of resorting to the collection of living specimens of possibly threatened species. The notion that to prove and establish the existence and identity of a species new to science it is necessary to collect a holotype is, I submit, outdated.

Christopher Lever, Newell House, Winkfield, Windsor, Berkshire SL4 4SE, UK.

\section{Cat amongst the freiras}

Since early 1987 the Madeira-based team of the Freira Conservation Project has carried out aggressive poisoning of the black rat Rattus rattus in the breeding area of the endemic Madeira freira Pterodroma madeira, using Klerat provided by ICI. The scheme has met with success and while no juveniles were recorded at the start of the project, the number of successfully fledged juveniles has increased over the years.

At the onset of the 1991 breeding season things augured well; the birds returned to their breeding grounds and were observed cleaning out their burrows. The first warning of trouble came in late June, when what appeared to be a dead bird was observed through binoculars on a breeding ledge. This exceptionally dangerous site was eventually visited on 1 July 1991. To our horror the remains of eight freiras were found and on a subsequent visit, two more, making a total of 10 dead freiras. If we consider these as breed- ing birds, from an estimated breeding population of 20-30 pairs, then the magnitude of the problem can be seen.

Almost certainly the culprit of this slaughter is a cat. Feral cats have been observed in the area and scats recovered, which contained white feathers. How to rid the area of cats in such wild terrain with unlimited cover is a major problem that must be overcome at all costs. I would welcome any advice on how to tackle this problem.

Francis Zino, Freira Conservation Project, Avenida do Infante 26, Rez-do-Chäo C, 9000 Funchal, Madeira.

\section{Lake Nakuru Black Rhinoceros Sanctuary}

I would like to comment on the article, Lake Nakuru Black Rhinoceros Sanctuary (Oryx, 24, 90-94).

This sanctuary was always intended as a sanctuary for both black and white rhinos, and although the article was about the black rhino, and probably at the time the article was written only black rhino were present in the sanctuary, this point should have been mentioned. Some years earlier the UK press had stated that the remaining government-owned white rhino had been killed at Meru Park after the Warden, Mr Peter Jenkins, had left there, and stated that these had been the last in Kenya. In fact, at that time, I was Warden at Solio Game Reserve and we had very healthy populations of both black and white rhinos. It was, indeed, due to excess numbers of both species that the Rhino Rescue started. Solio was the only place in Kenya free from poaching and over the previous 14 years the populations of both species had steadily increased to the point that Peter Jenkins and I decided to take action to relieve the pressure and set up rhino sanctuaries elsewhere. Peter was, at that time stationed at Mweiga Park Headquarters of the Aberdare Park, not far from Solio. Once the government Wildlife Conservation and Management Service started trapping, word got out about the large numbers of rhino in Solio and poaching began. 